\title{
NEMESÍTHETŐ ACÉLOK PLAZMANITRIDÁLÁSA
}

\section{PLASMA NITRIDING OF TEMPERED STEELS}

\author{
Kovács Dorina ${ }^{1}$, Fábián Enikő Réka ${ }^{2}$, Blücher József ${ }^{3}$, Dobránszky János ${ }^{4}$ \\ 1, 2, 3 BME Gépészmérnöki Kar, Anyagtudmány és Technológia Tanszék, \\ Magyarország, 1111 Budapest, Müegyetem rakpart 3. telefonszám: +36 1 463-1234 \\ ${ }^{4}$ MTA-BME Kompozittechnológiai Kutatócsoport \\ Magyarország, 1111 Budapest, Müegyetem rakpart 3. telefonszám: +36 1 463-1934 \\ ${ }^{1}$ kovacsdod@gmail.com \\ 2fabianr@eik.bme.hu \\ 3 jblucher@verzion.net \\ ${ }^{4}$ dobranszky.janos@eik.bme.hu
}

\begin{abstract}
A plasma-nitriding system was built by plans of professor Blücher at the BME Department of Materials Science and Engineering. The aim of this surface treatment equipment is to produce nitrided layers on different steels. The aim of our research work is to analyze with SEM-EDS and XRD the surface of tempered steel after plasma-nitriding. We made specimens in our laboratory and, for comparing, at an industrial partner in its equipment. Metallographic and hardness testing and microstructural characterization were performed.
\end{abstract}

Keywords: plasma-nitriding, tempered steel, metallography, XDR

\section{Összefoglalás}

A BME Gépészmérnöki Kar, Anyagtudomány és Technológia Tanszékén új plazmanitridáló berendezés és koptatóberendezés kezdte meg müködését. A berendezések Blücher József professzor tervei alapján készültek. A kutatómunka célja, hogy elsőként nemesíthető acélok, majd ausztenites és duplex korrózióálló acélok kopási tulajdonságait vizsgáljuk a plazmanitridálással létrehozott felületeken. Metallográfiai vizsgálattal, mikrokeménység-méréssel, pásztázó elektronmikroszkóppal és diffraktométeres vizsgálattal elemeztük a felületen kialakult réteg összetételét, vastagságát, keménységét. A mintákat mind ipari, mind laboratóriumi körülmények között plazmanitridáltuk. A vizsgálatok után a különböző technológiai változókkal készült mintákat összehasonlítva megállapítottuk, hogy a keménységben eltérés nem mutatkozik, kizárólag a réteg vastagsága és a felületen képződött rétegben létrejött fázisok mennyiségében mutatkozik eltérés.

Kulcsszavak: plazmanitridálás, nemesithető acélok, metallográfia, röntgendiffrakció

\section{A plazmanitridálásról}

A plazmanitridálás során a bejuttatott gáz nagy feszültség és kis nyomás hatására a két elektróda között (anódként kapcsolt munkadarab, katódként kapcsolt kemencefal) ionizálódik. A gáz halmazállapotú atomok gerjesztett állapotba kerülnek, és a legrövidebb úton ütköznek egymással, vala- 
mint bombázzák a munkadarabot. Ez a jelenség hőfelszabadulással és fényhatással jár, ezért is nevezik ködfénykisüléssel járó nitridálásnak. A folyamat $\sim 3$ torr $(400 \mathrm{~Pa})$ nyomáson, $\quad 500-520^{\circ} \mathrm{C}$-on, $\quad 700-800 \mathrm{~V}$ egyenfeszültségen megy végbe [1].

Indulásként a gázteret argon-hidrogén keverékkel töltik fel a rendszer átöblítése és a munkadarab tisztítása érdekében. Az ionizálódott atomok bombázzák a felületet, melyet porlasztásnak (angol kifejezéssel, elterjedten 'sputtering'-nek) neveznek. Ez a részfolyamat megtisztítja a felületet a maradt szennyeződésektől, zsírtól vagy oxidoktól, melyek megakadályozhatják a nitrogén diffúzióját. A többlépcsős tisztítási eljárás során nitrogéngázt vezetnek a kamrába. Az ionizáció, azaz a plazma létrejötte után a nitrogénionok bediffundálnak a felületbe, majd nitridet képeznek a vassal [1].

A plazmából beoldódó atomos nitrogén instabil FeN nitridet képez, emiatt tovább bomlik $\varepsilon$ - és $\gamma$-fázisra, valamint kialakul az ún. diffúziós (olykor: vegyületi) zóna [1].

$$
\begin{aligned}
& \mathrm{FeN} \rightarrow \mathrm{Fe}_{2} \mathrm{~N}+\mathrm{N} \\
& \mathrm{Fe}_{2} \mathrm{~N} \rightarrow \mathrm{Fe}_{3} \mathrm{~N}+\mathrm{N} \text { ( } \varepsilon \text {-fázis) } \\
& \mathrm{Fe}_{3} \mathrm{~N} \rightarrow \mathrm{Fe}_{4} \mathrm{~N}+\mathrm{N} \text { ( } \gamma^{\prime} \text {-fázis) } \\
& \mathrm{Fe}_{4} \mathrm{~N} \rightarrow \mathrm{Fe}+\mathrm{N} \text { (Fe/N diffúziós zóna) }
\end{aligned}
$$

A nitridált réteg két részből áll: egy külső, nagyon kemény, ún. vegyületi v. fehér rétegből, amely a plazmanitridálási tényezőktől és a kezelés időintervallumától függően elérheti a $20 \mu \mathrm{m}$-es vastagságot is [2], alatta pedig egy kisebb keménységü, kis mennyiségű oldott nitrogént tartalmazó diffúziós réteg található akár $0,6-0,8 \mathrm{~mm}$-es vastagságban $[3,4,5]$.

Az eljárással nagy kopásállóságú réteg alakítható ki a munkadarabra, csekély vetemedés és méretváltozás mellett. Az előállított felület utólagos megmunkálást nem igényel. A folyamat egyik legnagyobb előnye a hagyományos nitridálással szemben, hogy jól és könnyen szabályozható.

\section{A plazmanitridáló berendezés}

A berendezés (1.ábra) gázterét egy üvegbura képzi, mely jó demonstrációt és kiváló megfigyelési lehetőséget ad a plazmához. A bura belsejébe a gyors felmelegedés érdekében hőárnyékoló lemezek kerültek. Mindez egy köszörült alaplapon helyezkedik el, melyhez a gáz- és a nagyfeszültségü bevezetések csatlakoznak. A kamra nyomását egy vákuumpumpa biztosítja. A 700-800 V egyenfeszültséget két transzformátor sorba kapcsolásával érjük el.

A feszültség okozta ívkisülés elkerülése érdekében a nagyfeszültségü bevezetést megfelelően el kell szigetelni az áramkörbe nem kapcsolt fémalkatrészektől.

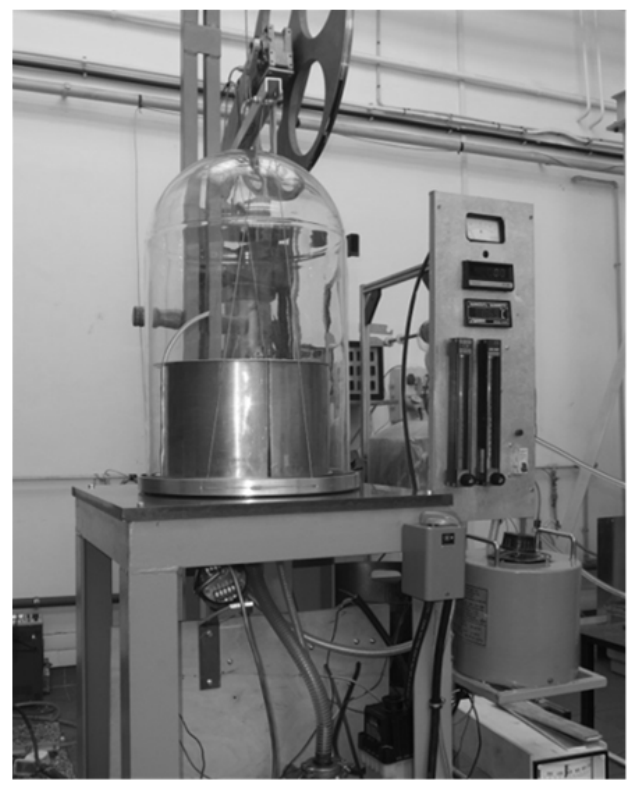

1. ábra. A saját épitésü plazmanitridáló berendezés

\section{Célkitűzések}

A kísérletek célja, hogy laboratóriumi és ipari körülmények között elemezzük és öszszehasonlítsuk a plazmanitridálással előállított kemény réteg tulajdonságait. Ehhez metallográfiai vizsgálat, keménységmérés és 
röntgendiffraktométeres (XRD) mérések segítik a munkánkat. A kopástesztekhez építettünk egy koptatóberendezést, mellyel a felületkezelt réteg kopási tulajdonságait vizsgálhatjuk adott terhelés mellett. Távlati célként összevetjük eredményeinket más kutatók kísérleti eredményeivel $[6,7,8]$.

\section{Kísérletek}

Elsőként AISI 4110 típusú, nemesíthető acélok plazmanitridálásával foglalkoztunk. Mind ipari, mind laboratóriumi körülmények között végzett kezelés után megvizsgáltuk a keletkezett kemény réteg felületén kialakult vegyületeket és a rétegvastagságokat. A próbatest méretei mindkét esetben megegyeznek, $12 \times 20 \times 2 \mathrm{~mm}$. Az elemzések keresztcsiszolati mintákon végzett metallográfiai vizsgálattal kezdődnek, majd a mikrokeménység-méréssel, SEM-EDS és XRD-vizsgálattal folytatódnak.

\subsection{Ipari minták}

A minták $520^{\circ} \mathrm{C}$-on, $80 \% \mathrm{~N}_{2}$ és $20 \% \mathrm{H}_{2}$ gázkeverék hozzáadása mellett 12, 24 és 40 órás kezelésen estek át (2. ábra és 3. ábra).

A különböző időtartamok a keménységet nem befolyásolják, vagyis a 12 és a 40 órásnál is a rétegek keménysége hasonló. A legkeményebb réteg 1620-1700 HV, az anyag belseje felé haladva pedig fokozatosan csökken. A fehér réteg vastagsága azonban már jelentősebb mértékben változik, amint ezt az 1. táblázat mutatja.

1. táblázat. A fehér réteg vastagsága különbözö idötartamokig plazmanitridált mintáknál

\begin{tabular}{|c|c|c|c|}
\hline Időtartam & $12 \mathrm{~h}$ & $24 \mathrm{~h}$ & $40 \mathrm{~h}$ \\
\hline Rétegvastagság, $\mu \mathrm{m}$ & 5,0 & 6,6 & 8,9 \\
\hline
\end{tabular}

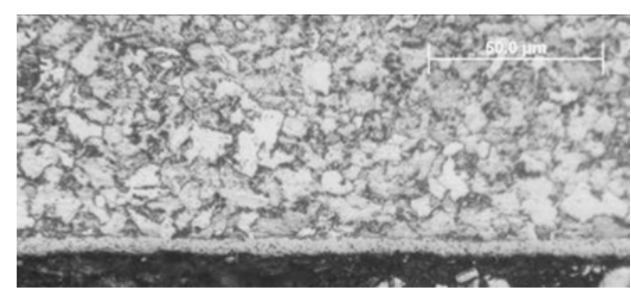

2. ábra. A 4110-es acélon 24 órás nitridálással képzödö réteg optikai mikroszkópi képe

A diffraktométeres vizsgálat $\mathrm{Cu}$-anód használatával történt, és minden minta esetében kimutatta a közel tisztán nitrides felületet. A hosszabb időtartamokon (4. ábra) megjelent a 44-1290 referenciájú, „ $\mathrm{Fe}_{1} \mathrm{C}$ Carbon Iron, C0.055Fe1.945” elnevezésü fázis is.

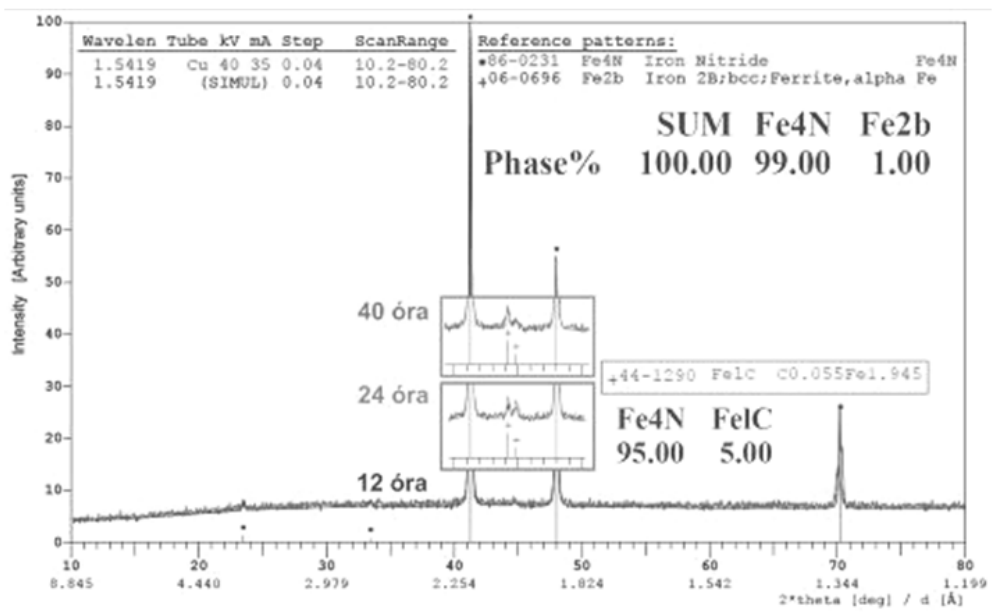

3. ábra. A diffraktométeres vizsgálat eredménye az ipari mintáknál 


\subsection{Laboratóriumi minták}

A mintákat $500^{\circ} \mathrm{C}$-on $80 \% \mathrm{~N}_{2}+20 \% \mathrm{H}_{2}$ gázkeverék hozzáadása mellett, 5 órán keresztül nitridáltuk. A kezdeti tisztíási nehézségek leküzdése után sikerült olyan próbatesteket készíteni, melyeken már jól vizsgálható nitridréteg keletkezett a felületen. Az eddig elkészült minták legnagyobb keménysége megközelítette az $1700 \mathrm{HV}$-t. A fehér réteg vastagsága meglepő módon már ilyen rövid idő alatt is átlagosan $7 \mu \mathrm{m}$ körüli (56. ábra). A fehér réteg keménysége az ipari berendezésben kezeltekével azonos értékeket mutatott (7. ábra).

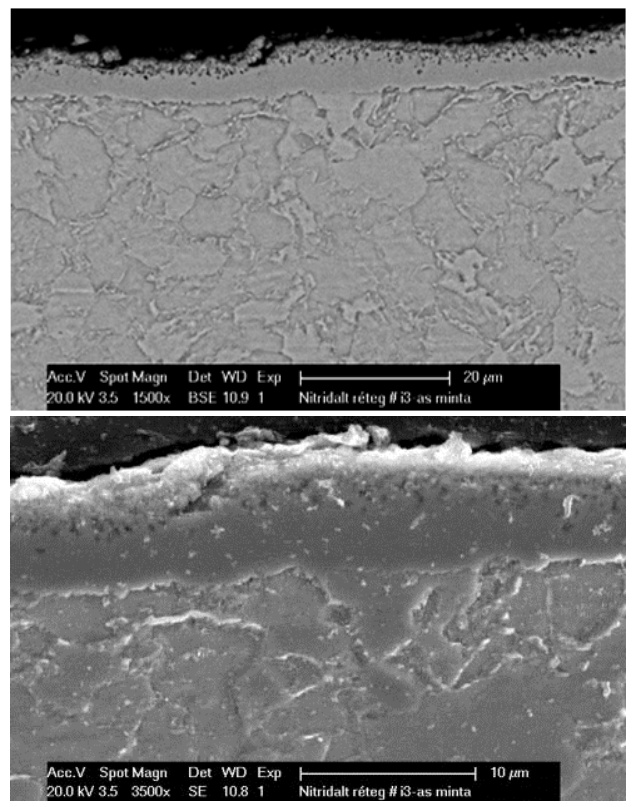

4. ábra. A 4110-es acélon 5 órás nitridálással kialakult réteg visszaszórtelektron-képe

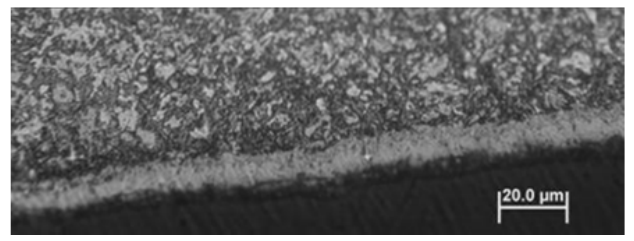

5. ábra. A 4110-es acélon 5 órás nitridálással képzödö réteg optikai mikroszkópi képe
Az első laboratóriumi mintánkon azonos feltételekkel végzett diffraktométeres mérés azonban eltérést mutatott az ipari mintákhoz képest. Nemcsak vas-nitrid keletkezett a felületen, hanem mellette különböző oxidok is megjelentek (8. ábra), amint ez már a minta felületének elszíneződéséből is következtethető volt.

A vákuumrendszer tömörtelenségét az ellenőrzések elvégzésével kizártuk. Nem zárható ki az, hogy a probléma a gázkeverék nem kellő tisztaságából, illetve a gázbevezető csővezetékek tömörtelenségéből adódhat. Nagy eséllyel az argonos öblítési és tisztítási szakasz nem tartott kellő ideig, ezért levegö maradhatott a bura alatt, a benne lévő oxigén szintén a plazmába keveredett, miközben már elkezdtük a minta fütését. Ezen a munkatér atmoszférájának monitorozásával kívánunk segíteni.

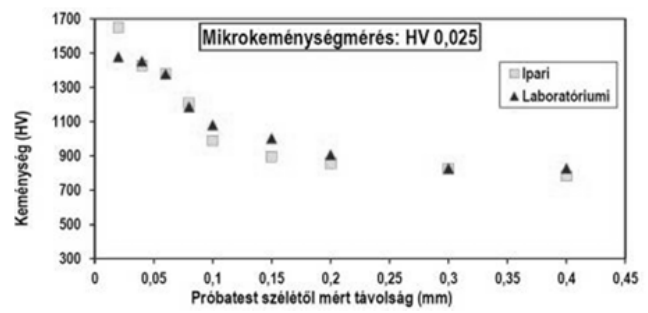

7. ábra. A keménység összehasonlitó diagramja az ipari és a laboratóriumi mintánál 


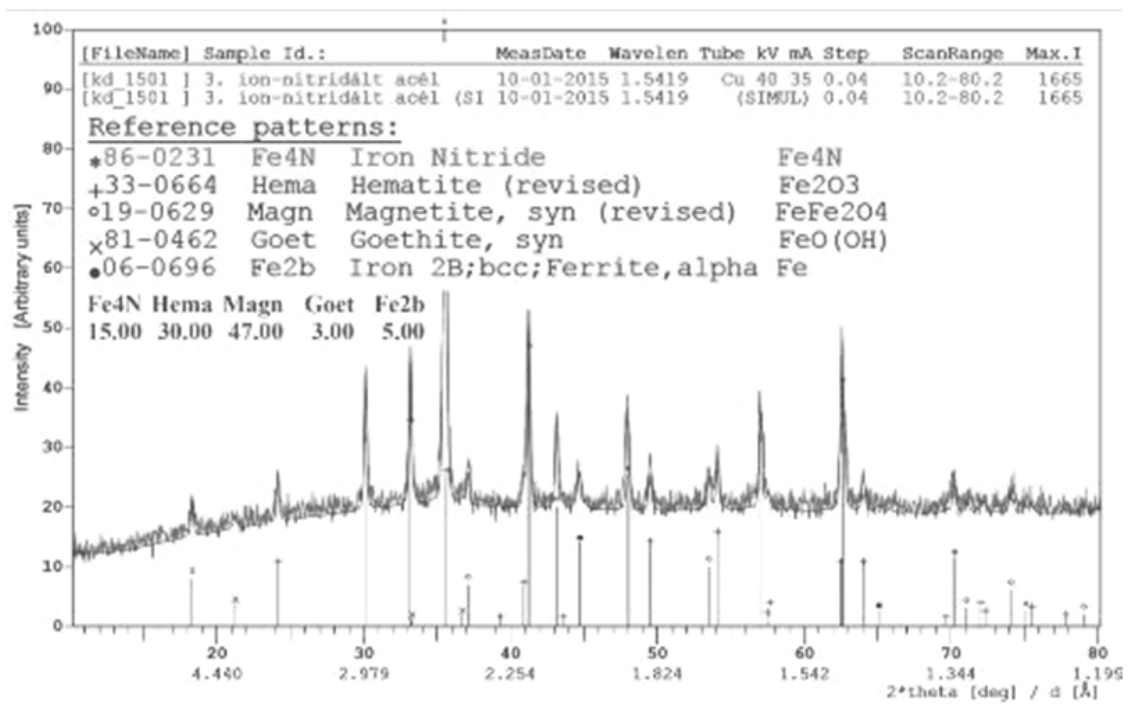

8. ábra. Az 5 óra időtartamig a laboratóriumi berendezésben plazmanitridált minta röntgendiffraktogramja

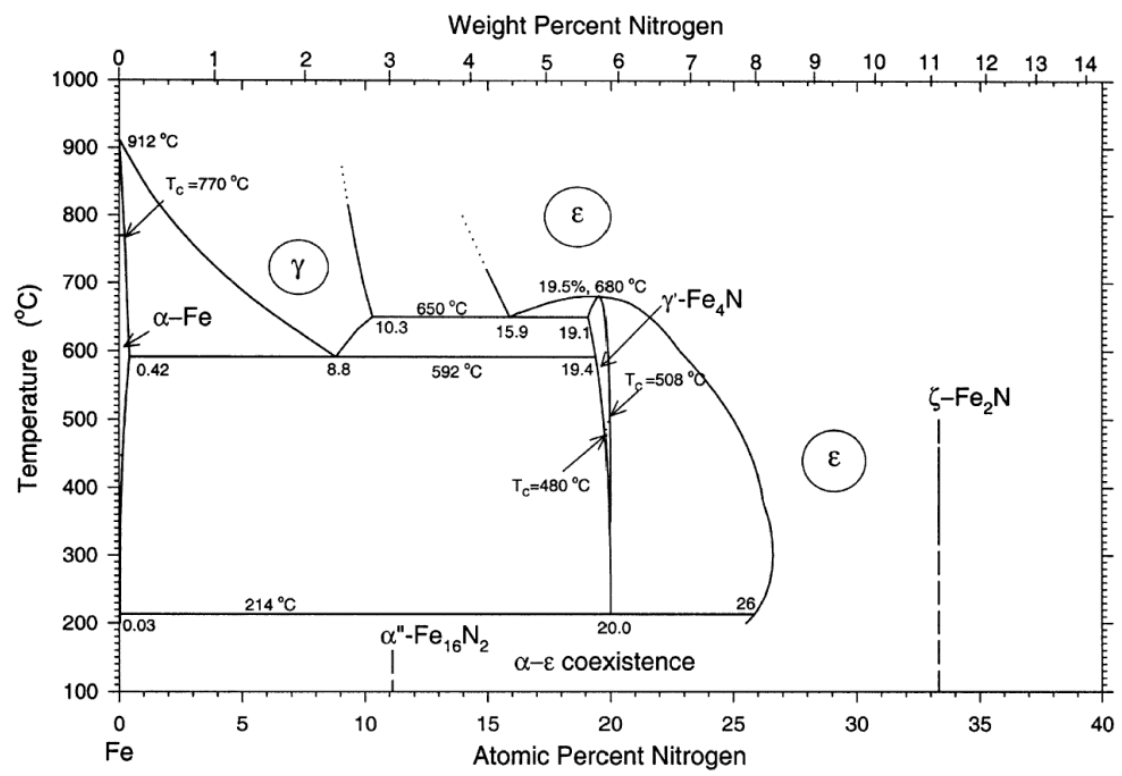

9. ábra. A teljes $F e-N$ fázisdiagram. Forrásmü: Du Marchie van Voorthuysen EH, Chechenin NC, Boerma DO: Low-Temperature Extension of the Lehrer Diagram and the Iron-Nitrogen Phase Diagram. Metallurgical and Materials Transactions A, Volume 33A, August 20022593. oldal 


\section{Következtetések}

$\mathrm{Az}$ eddigi kutatási eredményeinkböl megállapíthatjuk, hogy a fehér réteg kialakulása már rövidebb idejű plazmanitridálás során is végbemegy, ugyanolyan keménységü réteget hozva létre, mintha tovább kezelnénk a felületet, a vastagsága azonban nem ugyanolyan, az idő növekedésével a rétegvastagság is növekedik.

A jövőbeli tervek között nemcsak a koptatóvizsgálatok elvégzése szerepel, hanem a plazmanitridáló berendezés továbbfejlesztése is, annak a protokollnak a pontos kidolgozása, mellyel kiküszöbölhetőek a berendezés eddigi tesztelése során felmerült problémák. Emellett nemcsak nemesíthető acélok vizsgálatára fektetjük a hangsúlyt, hanem felvesszük a palettára az ausztenites és a duplex rozsdamentes acélokat is.

\section{Köszönetnyilvánítás}

A szerzők nagy-nagy köszönetüket fejezik ki mindazoknak a kollégáknak, akik a plazmanitridáló berendezés megépítésében elévülhetetlen segítséget nyújtottak: Oláh Sándor úrnak a villamos berendezésekért, Nyulász Pál úrnak a vezérlések megépítéséért, Mátyási Gyulának a forgácsolási megmunkálásokért, Ott Róbertnek a lézersugaras vágásért, valamint a teljes körủ gyártási háttértámogatásért a Fogaskerékgyár Kft. vezetőjének, Kovács Istvánnak.

\section{Szakirodalmi hivatkozások}

[1] Pye, D.: Practical Nitriding and Ferritic Nitrocarburizing. ASM International, $\mathrm{OH}$, 2003. 71-86.

[2] Edenhofer, B.: Production ionnitriding. in: Unterweiser P.M. (szerk.): Source book of nitriding. American Society for Metals, Metals Park OH, 1977. 181-187.

[3] Szombatfalvy Á.: A hökezelés technológiája. Müszaki Könyvkiadó, Budapest, 1985.

[4] Constant, A., Charbonnier, J-C: Principes de base des traitements thermiques, thermomécaniques et thermochimiques des aciers. PYC Edition, Paris, 1992.

[5] Marchev, K., Cooper, C. V., Blucher, J. T., Giessen, B. C.: Conditions for the formation of a martensitic single phase compound layer in ion-nitrided $316 \mathrm{~L}$ austenitic stainless steel. Surface and Coatings Technology, 99 (1998) 225-228.

[6] Kuzsella L., Frigyik G., Kocsisné Baán M., Varga Zs., Sávolyi S.: Plazmanitridálási kísérletek szerszámacélokon. XXVI. Hőkezelő és anyagtudomány a gyártásban konferencia és szakkiállítás. Balatonfüred, 2014. október 8-10. 246-251.

[7] Godzsák M.: Braunit vizsgálata. XXVI. Hökezelő és anyagtudomány a gyártásban konferencia és szakkiállítás. Balatonfüred, 2014. október 8-10. 218-223.

[8] Juhász Gy.: Ausztenites korrózióálló acélok nitridálási tapasztalatai. XXVI. Hőkezelő és anyagtudomány a gyártásban konferencia és szakkiállítás. Balatonfüred, 2014. október 810. 123-126. 